\title{
Las élites en América colonial (siglos XVI-XIX) Recopilación bibliográfica
}

\author{
Frédérique Langue \\ CNRS, Francia
}

\begin{abstract}
Este balance historiográfico descansa en una evaluación, tanto en términos cuantitativos como cualitativos, de los trabajos que se vinieron multiplicando sobre este tema en estos últimos años. Pese a la extrema variabilidad de las definiciones adelantadas por los distintos autores, le proporciona al lector una base representativa de la producción científica y de los intereses en juego en este campo de la historia económica, social, política y, en ciertos casos, cultural. Constituye asimismo un instrumento de consulta, a la par que un panorama muy flexible, de esta temática, teniendo en cuenta la distribución de los estudios especializados por regiones dentro del conjunto territorial americano.
\end{abstract}

Los motivos de esta recopilación remiten de entrada a un tema que venimos trabajando desde hace varios años, en una dedicación que dio lugar a unas cuantas publicaciones, reuniones, mesas redondas y otros seminarios especializados. El hecho de haber ampliado nuestra especialización territorial nos permitió sin lugar a dudas privilegiar la opción comparativa, tan provechosa a la hora de definir verdaderamente y de analizar el objeto de nuestro interés. El momento nos pareció además lo suficientemente oportuno para dar a conocer este trabajo bibliográfico: lo justifica sobremanera el lapso de tiempo que transcurrió desde los primeros estudios realizados sobre el tema y por lo tanto por la consecuente producción a nivel historiográfico que hace necesario una suerte de balance, un état des lieux, una evaluación tanto en términos cuantitativos como cualitativos. Por otra parte, el fenómeno de moda que parece inducir a muchos estudiosos o realizadores de tesis a que elijan esta orientación, hace imprescindible una reconsideración de los trabajos existentes, una selección de trabajos perti-

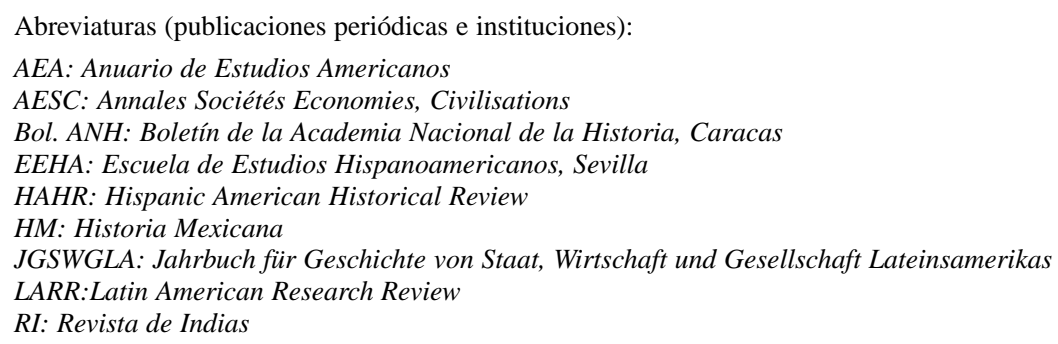


nentes referentes al tema y que permita por lo tanto disponer de referencias sólidas, y más cuando no existía hasta la fecha ningun recuento o recopilación bibliográfica sobre el particular.

Otra razón anexa, ligada precisamente al volumen de la producción en estos últimos años, descansa en la multiplicidad de las definiciones, que tienen que ver con factores tan diversos como la formación de los autores, sus opciones ideológicas (siendo sin embargo esta explicación más valedera para el período más reciente), el área considerada, la época: el período pre-independentista da lugar a unos deslizamientos de conceptos, a unas dudas heurísticas o en todo caso a unas cuantas imprecisiones y oscilaciones de una caracterización a otra.

Esta recopilación, por más que sea el fruto de una larga dedicación y de una colaboración constante con otros especialistas, no pretende ser exhaustiva. En el repertorio de los títulos olvidados, no faltará evidentemente alguna que otra publicación de dificíl acceso pero de imprescindible lectura para quien tenga la suerte de haberla consultado. Creemos, sin embargo, dar a conocer con esta bibliografía -cuya consulta y búsqueda la facilita la utilización de palabras claves- una base representativa de la producción y de los intereses en este campo de la historia económica, social, política y, en ciertos casos, cultural, y proporcionar un punto de partida, un instrumento de consulta, a la par que un balance muy flexible de la cuestión. No trae ningún juicio de valor respecto a las obras incluidas. Más bien insistimos aquí en el aspecto cuantitativo de esta producción historiográfica y en la distribución por regiones dentro del conjunto territorial americano y por eso mismo se da al lector una idea de la representatividad del tema dentro de las preocupaciones americanistas del momento. Por esta razón, incluimos en esta bibliografía trabajos que, aunque traten aparentemente otros temas, en la mayoría afines, u otras áreas (como Brasil), no dejan de abordar esta problemática en sus planteamientos.

\section{América Diversos}

Atienza, Julio de: Títulos nobiliarios hispanoamericanos, Madrid, Aguilar, 1947. Fuentes / América / Aristocracia / Élites / Títulos Nobiliarios / siglos XVI-XX.

Balmori, Diana: "Family and Politics: Three Generations (1790-1890)", Journal of Family History, 1985, vol. 10, n. ${ }^{\circ} 3$, págs. 247-257.

América siglo XVIII, XIX / / Élites políticas / Economía / Parentesco (relaciones de). 
Balmori, D.; Voss, S., y Wortman, M.: Notable Family Networks in Latin America, Chicago-London, The University of Chicago Press, 1984, VII-290 págs.

América siglo XVIII, XIX, XX / Élites / Parentesco (relaciones de) / Comerciantes / México / Chile / América Central / Buenos Aires.

Balmori, D. y otros: Las alianzas de familias y la formación del país en América Latina, México, FCE, 1990, 335 págs.

América siglo XVIII, XIX, XX / Élites / Parentesco (relaciones de).

Brading, David A.: "La ciudad en la América Borbónica: élite y masas”, Ensayos histórico-sociales sobre la urbanización en América Latina, Buenos Aires, CLACSO / Ediciones SIAP, 1978, págs. 197-217.

América, México, siglo XVIII / Élites / Comerciantes / Clases populares / Lima / México / Querétaro / Zacatecas / Guanajuato / / Minería / Obrajes / Iglesia / Crédito / Conventos / Censos.

Bravo Ugarte, P. José: "Títulos nobiliarios hispanoamericanos", Memorias de la Academia Mexicana de la Historia, julio-septiembre 1956, tomo XV, n. ${ }^{\circ} 3$, págs. 258-270.

Fuentes / América / Aristocracia / Élites / Títulos Nobiliarios / siglos XVI-XX.

Burkholder, Mark A.: "Titled nobles, Elites, and Independence: Some Comments", LARR, 1978, tomo XIII, n. ${ }^{\circ}$ 2, págs. 290-295.

Aristocracia / Élites / Independencia / Nueva España / Títulos nobiliarios / Ciudad de México / Comerciantes / Parentesco (Relaciones de) / Compadrazgo.

Cadenas Allende, Francisco de: "La nobleza en Hispanoamérica", separata de Hidalguía, Madrid, Instituto Salazar y Castro / CSIC, 1978.

América / Nobleza / Legislación / Tíulos nobiliarios / Hidalguía / Limpieza de sangre.

Chevalier, François: "La tierra: gran propiedad, señores y trabajo indígena (historiografía de América, periodo español)", IV Conversaciones Internacionales de Historia. Balance de la Historiografía sobre Iberoamérica (1945-1988), Pamplona, Ediciones Universidad de Navarra, 1989, págs. 221-290.

América / Nueva España / Perú (Alto) / Tierras / Haciendas / Sociedad / Terratenientes / Mano de obra / Comunidades indígenas / Trabajo (compulsivo) / yanaconas / Historiografía.

Florescano, Enrique (Coord.): Orígenes y desarrollo de la burguesía en América Latina 1700-1955, México, Editorial Nueva Imagen, 1985, 662 págs.

América / siglo XVIII, XIX, XX / Élites sociales / Iglesia / Burguesía / Comerciantes / Nueva España / Río de la Plata / Lambayeque.

Hoberman, Louisa S.; Socolow, Susan M., ed.; Cities and Society in Colonial Latin America, Albuquerque, University of New Mexico Press, 1986, X-350 págs. América / siglos XVIII, XIX, XX / Urbana (población) / Ciudades / Sociedad / Comercio / Religiosas (comunidades) / Ejército / Artesanos / Pobres.

Konetzke, Richard: "La formación de la nobleza en Indias", Estudios Americanos, 1951, tomo III, n. ${ }^{\circ} 10$, págs. 329-257.

América / siglos XVI-XVIII / Nobleza / Élites / Títulos nobiliarios / Fueros / Recopilación de Leyes de Indias. 
Langue, Frédérique: "Las élites en América española, actitudes y mentalidades", Boletín Americanista, 1992-1993, año XXXIII, págs. 123-139.

América / Élites / Mentalidades (Historia de las) / Mineros / Comerciantes / Haciendas / Nueva España / Venezuela / Mantuanos.

Lavrin, Asunción (comp.): Sexuality and Marriage in Colonial Latin America, Lincoln, Nebraska, University of Nebraska Press, "Latin American Studies Series", 1989, 349 págs.

América / Élites / Mentalidades (Historia de las) / Familia / Matrimoniales (estrategias) / Río de la Plata / Guadalajara / Brasil.

Lira Montt, Luis: "Privilegio nobiliario otorgado por Carlos IV al ejercicio de la profesión minera en Indias”, Boletín de la Academia Chilena de la Historia, Santiago, 1973, n. ${ }^{\circ} 87$, págs. 273-288.

Nobleza / América / Hidalguía / Limpieza de sangre / Minería / Fueros / Estatuto social / Velásquez de León (Joaquín) / Ordenanzas de Nueva España / Seminario de Minería (Real) / Recopilación de Leyes de Indias.

— "Normas sobre la concesión de títulos de Castilla a los residentes en Indias", separata de Hidalguía, Madrid, 1981.

Nobleza / Títulos nobiliarios / Hidalguía / Limpieza de sangre.

- "Las relaciones de méritos y servicios de los americanos y su valor probatorio de nobleza", separata de Estudios genealógicos en honor de Vicente de Cadenas y Vicent (XXV Aniversario de Hidalguía), Madrid, Instituto Salazar y Castro / CSIC, octubre 1988.

Nobleza / Hidalguía / Limpieza de sangre / Militares (Ordenes) / Chile / Nueva España / Guatemala / Perú / Real Compañía de Guardias Marinas.

Lohmann Villena, Guillermo: Los americanos en las órdenes nobiliarias (15291900), Madrid, CSIC / Instituto G. Fernández de Oviedo, 1947, 2 vol., 476 y 540 págs. (reed. 1993).

Nobleza / Ordenes militares / nobiliarias / Nueva España / Perú.

Mörner, Magnus: "Economic Factors and Stratification in Colonial Spanish America with Special Regard to Elites", $H A H R$, 1983, tomo 63, n. ${ }^{\circ}$ 2, págs. 335-369.

Élite / Economía / Cultura / Europa / Nueva España / Alto Perú / Lambayeque.

- "La sociedad (Siglos XVI-XIX). Balance de la historiografía", IV Conversaciones Internacionales de Historia. Balance de la Historiografía sobre Iberoamérica (1945-1988), págs. 557-591.

Historia social / Historiografía / mentalidades / Clases sociales / Ciudades / Parentesco.

Pérez Vila, Manuel: "Cultura de élites y cultura popular en la América del barroco", en Memoria del quinto Congreso venezolano de Historia [1986], Caracas, Academia Nacional de la Historia, 1992, tomo II, págs. 383-408. Historia social / América / Venezuela / siglos XVIII / Cultura / Diversiones / Teatro. 
Schwartz, Stuart B.: "State and Society in Colonial Spanish America: An Opportunity for Prosopography", in Richard Graham \& Peter H. Smith: New Approaches to Latin American History, Austin, University of Texas Press, 1974, págs. 3-35.

Biografía / Conquistadores / Emigración / Aristocracia / Élites / Cabildo / Iglesia / Audiencia / Administración colonial / Universidades / Mentalidades / Ciudad de México / Chile / Popayán / Guatemala.

Vila Vilar, Enriqueta: "Los Corzo: un clan en la colonización de América. Apuntes para su historia”, AEA, 1985, vol. XLII, págs. 1-42.

Emigración / Córcega / Sevilla / América / Perú / Tierra Firme / siglos XVI-XVIII / Comerciantes / Mercaderes / Consulados de comercio / Mayorazgos / Ordenes militares / Hidalguía.

- Los Corzo y los Mañara. Tipos y arquetipos del mercader con América, Sevilla, EEHA / Junta de Andalucía, 1991, 321 págs.

Emigración / Córcega / Sevilla / América / Perú / Tierra Firme / siglos XVI-XVIII / Comerciantes / Mercaderes / Consulados de comercio / Mayorazgos / Ordenes militares / Hidalguía.

\section{Brasil}

Flory, Rae; Grant Smith, David: "Bahian Merchants and Planters in the Seventeenth and Early Eighteenth Centuries", HAHR, 1978, tomo 58, n. ${ }^{\circ}$, págs. 571-594.

Aristocracia / Terratenientes / Criollos / Comerciantes / Bahía / Siglos XVII-XVIII / limpieza de sangre / matrimonio / Cabildo / burguesía.

Kennedy, John Norman: "Bahian Elites, 1750-1822”, HAHR, 1973, tomo 53, n. 3, págs. 415-439.

Bahía / siglos XVIII-XIX / Independencia / Terratenientes / Comerciantes / Burocracia / Milicia.

Kuznesof, Elizabeth A.: "The Role of the Merchants in the Economic Development of Sao Paulo, 1765-1850”, HAHR, 1980, tomo 60, n. 4, págs. 571-592.

Ciudades / siglos XVIII-XIX / Comercio / terratenientes / Élite / Burocracia / Milicia / Cabildo / Matrimonio / Inmigración.

Metcalf, Alida C.: Families of Planters, Peasants, and Slaves: Strategies for Survival in Santana de Paranaiba, Brazil, 1720-1820, Ph.D., University of Texas at Austin, 1983.

Élite / Brasil / São Paulo / Frontera / Sertão / Minas Gerais / Minería / Familia / Matrimonio / Tierra.

- "Fathers and Sons: The Politics of Inheritance in a Colonial Brazilian

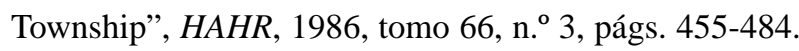

Élite / Brasil / São Paulo / Frontera / Sertão / Minas Gerais / Minería / Familia / Matrimonio / Tierra. 
Nazzari, Muriel: "Parents and Daughters: Change in The Practice of Dowry in Sao Paulo (1600-1770)", HAHR, November 1990, tomo 70, n. ${ }^{\circ}$ 4, págs. 639-665. Brasil / Siglos XVII-XVIII / Familia / Minas Gerais / Minería / Haciendas / Matrimonio.

- Disappearance of the Dowry: Women, Families and Social Change in Sao Paulo, Brazil, 1600-1900, Stanford, University Press, 1991.

Siglos XVII-XIX / Frontera / Minas Gerais / Familia / Matrimonio.

Ramos, Donald: "Marriage and the Family in Colonial Vila Rica", HAHR, 1975, tomo 55 n. $^{\circ} 2$, págs. $200-225$.

Brasil / siglo XVIII / Familia / Censos / Demografía.

\section{Cuba}

Bahamonde, A.; Cayuela, J.: Hacer las Américas, las élites coloniales cubanas (siglo XIX), Madrid, Alianza América, 1992, 390 págs.

Élites / Independencia / Criollos / Emigración / Tierras / Ingenios / Oligarquía / siglos XVIII-XIX.

Barcia, M. ${ }^{a}$ Carmen: "Táctica y estrategia de la burguesía esclavista de Cuba ante la abolición de la esclavitud", Estudios de Historia Social, 1988, núms. 44-47, págs. 137-148.

Calavera Vaya, Ana María: "Élites y mercado de mano de obra en Cuba 18251930”, Quinto Centenario, 1989, núm. 15, págs. 133-147.

Élites / Independencia / Criollos / Emigración / Tierras / Ingenios / Mano de obra / Oligarquía / siglos XVIII-XIX.

Fernández, José G.: "El nexo colonial de una transición: Élite antillana y Capitanes Generales de Cuba", en Cuba la perla de las Antillas. Actas de las I Jornadas sobre "Cuba y su historia”, Madrid, CSIC / Doce Calles, 1994, págs. 239-248.

Élites / Independencia / Criollos / Administración colonial / Tierras / Ingenios.

Ely, Robert T.: Comerciantes cubanos del siglo XIX, La Habana, 1960.

Élites / Independencia / Criollos / Emigración / Tierras / Ingenios / Oligarquía / siglos XVIII-XIX.

Knight, Franklin W.: Slave Society in Cuba during the Nineteenth Century, University of Wisconsin Press, Madison, 1970, 228 págs.

Élites / Independencia / Criollos / Emigración / Tierras / Ingenios / Mano de obra / Oligarquía / siglos XVIII-XIX.

Tornero Tinajero, Pablo: "Hacendados y desarrollo azucarero cubano (17631818)", RI, julio-diciembre 1978, tomo XXXVIII, núms. 153-154, págs. 715-737.

Hacendados / Criollos / Iglesia / Nobleza / Familias (grandes) / Comerciantes / Burguesía / Administración colonial / Ingenios de azúcar / Mano de obra esclava. 
- "El suministro de mano de obra esclava en Cuba. Estado español y oligarquía criolla (1765-1820)", en Cuba la perla de las Antillas. Actas de las I Jornadas sobre “Cuba y su historia”, págs. 313-324.

Hacendados / Criollos / Nobleza / Familias (grandes) / Comerciantes / Oligarquía / Administración colonial / Ingenios de azúcar / Mano de obra esclava.

\section{Chile}

Amunategui Solar, Domingo: La sociedad chilena del siglo XVIII: mayorazgos y títulos de Castilla, Santiago, 1901-1904, 3 vols.

Nobleza / Títulos nobiliarios / Ordenes militares / Haciendas / Mayorazgos.

Barbier, Jacques A.: "Elite and Cadres in Bourbon Chile", HAHR, 1972, tomo 52, n. ${ }^{\circ}$, págs. 416-435.

Chile / Siglos XVII-XVIII / Administración colonial / Reformas borbónicas / Haciendas / Familias (grandes) / Matrimonios.

Bauer, Arnold Jr.: Chilean Rural Society from Spanish Conquest to 1930, Cambridge, Cambridge University Press, 1975, 265 págs.

Chile / Conquistadores / Nobleza / Haciendas / Inquilinos / Familias (grandes).

Couyomdjian, Juan Ricardo: "Los magnates chilenos del siglo XVIII", Revista Chilena de Historia y Geografía, 1968, n. ${ }^{\circ}$ 136, págs. 315-322.

Comerciantes / Matrimonios / Haciendas / Títulos nobiliarios.

Cuadra, Guillermo de la: "Origen de doscientas familias coloniales de Santiago", Revista Chilena de Historia y Geografía, 1901, tomos XI, XII, XIII, XIX.

Chile / Conquistadores / Haciendas / Encomiendas.

Flusche, Della M.; Korth, Eugene H.: “A Dowry Office In Seventeenth-Century Santiago", The Historian, 1987, Vol. 49, n.o 42, págs. 204-222.

Derecho indiano / Chile / Santiago / Siglo XVII / Nobleza / Encomienda / Familia.

Góngora, M.: "Los "hombres ricos" de Santiago y de La Serena a través de las cuentas del Quinto Real, 1567-1677", Revista Chilena de Historia y Geografía, 1963, n. ${ }^{\circ} 131$.

Conquistadores / Aristocracia / Encomienda / Haciendas / Fiscalidad.

- Encomenderos y estancieros. Estudios acerca de la constitución social aristocrática de Chile después de la conquista 1580-1660, Santiago de Chile, Universidad de Chile (sede de Valparaíso), 1970.

Conquistadores / Aristocracia / Encomienda / Haciendas.

— “Urban Stratification in Colonial Chile", HAHR, 1975, tomo 55, n. o 3, págs. 421-448.

Conquistadores / Aristocracia / Santiago / Encomienda / Haciendas. 
Korth, Eugene; Flusche, Della: "Dowry and Inheritance in Colonial Spanish America: Peninsular Law and Chilean Practice", The Americas, April 1987, vol. 43 , n. ${ }^{\circ}$, págs. 395-410.

Derecho indiano / Chile / Familia.

Lamar, Marti: “'Choosing' Partible Inheritance: Chilean Merchant Families, 17951825”, Journal of Social History, Fall 1994, vol. 28, n. ${ }^{\circ}$ 1, págs. 125-145.

Comerciantes / Siglo XVIII / Independencia / Familias / Parentesco.

Lowenthal Felstiner, Mary: "Kinship Politics in the Chilean Independence Movement”, HAHR, 1976, tomo 56, n. ${ }^{\circ} 1$, págs. 58-80.

Conquistadores: Élites / Matrimonios / Familias (grandes) / Vascos / Administración colonial / Criollos / Poder político / Mayorazgos.

Ramón, José Antonio de: "La sociedad española de Santiago de Chile entre 1581 y 1596. Estudio de grupos", Historia, 1965, n. ${ }^{\circ} 4$.

Santiago / Siglo XVI / Conquistadores / Encomienda.

- "Mercaderes en Lima, Santiago de Chile, Buenos Aires, 1681-1696", Historia Urbana. Una metodología aplicada, Buenos Aires, Ed. SIAP, 1978. Virreinato del Perú / Río de la Plata / Santiago / Siglo XVII / Comerciantes.

- Santiago de Chile 1541-1991. Historia de una sociedad urbana, Madrid, Mapfre, 1992, 342 págs.

Santiago / Siglos XVI-XX / Historia urbana / Conquistadores / Encomienda / Élites / Comerciantes / Independencia.

Retamal Favereau, Julio; Celis Atria, Carlos, y otros: Familias fundadoras de Chile 1540-1600, Santiago, Ed. Zig-Zag, 1992, 828 págs.

Santiago / Siglos XVI-XVII / Conquistadores / Encomienda.

Thayer Ojeda, Tomás: "Biografías de conquistadores", Revista Chilena de Historia y Geografía, 1923, vol. 48, n. ${ }^{\circ}$ 52, págs. 201-209.

Chile / Aristocracia / Conquistadores / Encomienda / Comercio / Familias (grandes).

- Notas genealógicas para la historia social de Valparaíso, Valparaíso, Impr. Roma, 1934, 121 págs.

Chile / Valparaíso / Conquistadores / Comercio / Familias (grandes).

Vicuña Mackenna, Benjamín: Los orígenes de las familias chilenas, Santiago, Ed. G.E. Miranda, 1903.

Chile / Aristocracia / Conquistadores / Encomienda / Comercio / Familias (grandes).

Zúñiga, Juan Pablo: Espagnols d'outre-mer. Emigration, reproduction sociale et mentalités à Santiago du Chili au XVIIe siècle, Tesis de doctorado, Institut Universitaire Européen, Florence, Département d'Histoire et Civilisation, janvier 1995, 561 págs. + anexos.

Chile / Aristocracia / Conquistadores / Encomienda / Comercio / Emigración / Familias (grandes) / Mentalidades. 


\section{Ecuador / Audiencia de Quito}

Buschges, Christian: Die Quitener Elite in der späten Kolonial zeit (1767-1812), Hausarbeit zur Magistrerprüfung, Philosophische Fakultat der Universitat zu Köln, 1991, 163 págs.

Virreinato del Perú / Quito / Siglo XVIII / Audiencia / Títulos nobiliarios / Aristocracia / Ordenes religiosas / Cofradías / Milicias / Tierra / Haciendas / Comercio / Mayorazgos / Jesuitas / Emancipación / Rebeliones.

Cubitt, David: "La composición social de una élite hispano-americana a la Independencia: Guayaquil en 1820", Revista de Historia de América, juliodiciembre de 1982, n. ${ }^{\circ}$ 94, págs. 7-31.

Quito (Presidencia de) / Guayaquil / Comerciantes / Cultivadores / Cacao / Gran Colombia / Diputados / Cabildo / Ayuntamiento / Independencia.

Ortiz de la Tabla, Javier: "De hidalgo castellano a empresario colonial. Rodrigo de Salazar, encomendero y obrajero de Quito 1510-1584", AEA, 1985, XLIII, págs. 43-126.

Audiencia de Quito / Lima / Otavalo / Encomienda / Haciendas / Obrajes / Conquistadores / Hidalguía / Nobleza.

- "Modelos peninsulares en la estratificación social del Ecuador", Europa e Iberoamérica: cinco siglos de intercambios. Actas del IX Congreso Internacional de Historia de América (AHILA), AHILA / Junta de Andalucía, Sevilla, 1992, tomo I, págs. 99-105.

Ecuador / Audiencia de Quito / Conquistadores / siglos XVI - XVII / parentesco / Ejército / Cabildo / Mentalidades / Nobleza / Hidalguía.

- Los encomenderos de Quito 1534-1660, Sevilla, EEHA, 1993, XVI-377 págs. Audiencia de Quito / Siglos XVI-XVII / Otavalo / Encomienda / Haciendas / Obrajes / Conquistadores / Hidalguía / Nobleza / Linajes.

Super, John: "Empresarios quiteños en 1580-1620”, Revista del Archivo Histórico del Guayas, n. ${ }^{\circ}$ 16, Guayaquil, 1979.

Quito / Conquistadores / Encomiendas / Obrajes.

- "Partnership and Profit in the Early Andean Trade: the Experiences of Quito Merchants, 1580-1610”, Journal of Latin American Studies, 1979, tomo II, n. ${ }^{\circ}$, págs. 265-281.

Quito / Conquistadores / Encomiendas / Obrajes / Comerciantes / siglos XVI-XVII.

\section{Guatemala}

García Giráldez, Teresa: "Las redes familiares vascas en las instituciones coloniales de Guatemala", Memoria, creación e historia: luchar contra el olvido, coord. M. Izard; P. García Jordán, y J. Laviña, Barcelona, Universidad de Barcelona, 1994, págs. 145-164.

Siglos XVII-XVIII / Administración colonial / Haciendas / Familias (grandes / vascos. 
Gordillo Miranda, René Humberto: Los comerciantes en la ciudad de Guatemala en la segunda mitad del siglo XVIII, Guatemala, Universidad de San Carlos, 1980, 186 págs.

Siglo XVIII / Administración colonial / Haciendas / Familias (grandes) / vascos / Comerciantes.

Palma Murga, Gustavo Enrique: "Núcleos de poder local y relaciones familiares en la ciudad de Guatemala a finales del siglo XVIII", Mesoamérica, 1986, vol. 7 , n. ${ }^{\circ} 12$, págs. 241-308.

Ciudad de Guatemala / Administración colonial / Haciendas / Familias (grandes) / Cabildo.

Sánchez, Evelyne: Les élites de Nueva Guatemala, 1770-1821. Réseaux, clivages et groupes de pression à la veille de l'Indépendance, Université de ToulouseLe Mirail / UFR d'Histoire, 1993, Mémoire de Maîtrise (tesis de maestría).

Siglos XVII-XVIII / Administración colonial / Haciendas / Familias (grandes) / cabildo / Independencia.

Sanchiz Ochoa, Pilar: Los hidalgos de Guatemala, realidad y apariencia en un sistema de valores, Universidad de Sevilla, Publicaciones del Seminario de Antropología Americana, 1976, 193 págs.

Guatemala / Siglos XVI-XVIII / Nobleza / Haciendas / Hidalguía / Mentalidades.

- "Poder y conflictos de autoridad en Santiago de Guatemala durante el siglo XVI”, AEA, 1992, tomo XLIX, págs. 21-54.

Guatemala / Siglo XVI / Cabildo / Poder político / Nobleza / Haciendas / Hidalguía.

Stone, Samuel Z.: The Heritage of the Conquistadors: Ruling Classes in Central America from the Conquest to the Sandinistas, Lincoln, University of Nebraska Press, 1990.

Guatemala / Conquistadores / Élites / Administración colonial / Haciendas / Familias (grandes) / vascos.

Webre, Stephen: The Social and Economic Bases of Cabildo Membership in Seventeenth-Century Santiago de Guatemala, Ph. Tulane University Press / UMI, 1992, 373 págs.

Guatemala / Siglo XVII / Administración colonial / Haciendas / Familias (grandes) / vascos / Cabildo.

\section{Nueva España}

Alberro, Solange: "El indio y el criollo en la visión de las élites novohispanas, 1771-1811. Contribución a una antropología de las Luces”, en Cincuenta años de la historia en México, A. Hernández Chávez y M. Miño Grijalva coord., México, El Colegio de México, 1991, págs. 139-159.

Estructura social / Criollismo / Emancipación / Independencia / Mentalidades. 
- Les Espagnols dans le Mexique colonial. Histoire d'une acculturation, Paris, Armand Colin, 1992, 131 págs. (existe traducción en español, FCE).

Siglos XVI-XVII / Españoles / Criollos / Mentalidades.

Altman, Ida: The Marqueses of Aguayo: a family and estate history, Tesis de maestría, Universidad de Texas, 1972.

Nueva España / siglos XVI-XVIII / Estructura social / Propiedades (grandes) / Haciendas / Nobleza / Élites / Sonora / Coahuila / Nuevo León / Provincias Internas / Familias (grandes).

- "A Family and Region in the Northern Fringe Lands: The Marqueses de Aguayo of Nuevo León and Coahuila", en Ida Altman and James Lockhart, eds.: Provinces of Early Mexico, Los Angeles, University of California, 1976, págs. 253-272.

Nueva España / siglos XVI-XVIII / Estructura social / Propiedades (grandes) / Haciendas / Nobleza / Élites / Sonora / Coahuila / Nuevo León / Provincias Internas / Familias (grandes) / Frontera (zona de).

Alvarado Morales, Manuel: "El cabildo y regimiento de la ciudad de México en el siglo XVII. Un ejemplo de oligarquía criolla", $H M$, abril-junio de 1979 , tomo XXVIII, n. ${ }^{\circ}$ 4, págs. 489-514.

México / Élite / Oligarquía / Comerciantes / Cabildo / Poder político.

Bakewell, Peter J.: Minería y sociedad en el México colonial. Zacatecas, 15461700, México, FCE, 1976, 388 págs.

Zacatecas / Siglos XVI-XVII / Minería de la plata / Aristocracia / Títulos nobiliarios / Haciendas / Cabildo.

Barrett, Ward: The Sugar Hacienda of the Marqueses del Valle, Minneapolis, 1970. (Existe traducción en español, S. XXI, 1977).

Nueva España / Oaxaca / Conquistadores / Haciendas / Aristocracia / Títulos nobiliarios.

Bertrand, Michel: "Sociétés secrètes et finances publiques: fraudes et fraudeurs à Veracruz aux XVIIe et XVIIIe siècles”, Mélanges de la Casa de Velázquez, 1990, tomo XXVI, n. ${ }^{\circ}$ 2, págs. 103-128.

Comerciantes / Administración colonial / Élites secundarias / Oficiales reales / siglos XVII-XVIII.

— “Clientélisme et pouvoir en Nouvelle-Espagne (1680-1770)", Cultures et sociétés Andes et Méso-Amérique. Mélanges en hommage à Pierre Duviols, Aix-en-Provence, Publications de l'Université de Provence, vol. I, págs. 141-151.

Comerciantes / Administración colonial / Élites secundarias / Oficiales reales / siglos XVII-XVIII.

- "De la richesse en Amérique: la genèse des patrimoines familiaux des officiers de finances de Nouvelle-Espagne (XVIIe-XVIIIe siècles)", Revue d'Histoire Moderne et Contemporaine, núms. 41-42, avril-juin 1994, págs. 221-236.

Comerciantes / Administración colonial / Élites secundarias / Oficiales reales / Zacatecas / Veracruz / siglos XVII-XVIII. 


\section{FRÉDÉRIQUE LANGUE}

Booker, Jackie Robinson: Veracruz Merchants, 1770-1829. A Mercantile Elite In Late Bourbon And Early Independent Mexico, Boulder, Westview Press, 1993.

Comerciantes / Instituciones / Consulados de comercio / siglos XVIII-XIX / Independencia / Élite / Reformas borbónicas.

Borchart de Moreno, Christiana: "Los miembros del Consulado de México en la época de Carlos III", JGSWGL, 1977, n. ${ }^{\circ} 14$, págs. 134-160.

Ciudad de México / Consulado de comercio / Comerciantes / Cabildo / Reformas borbónicas.

- Los mercaderes y el capitalismo mercantil en México (1750-1778), México, FCE, 1984, 306 págs.

Ciudad de México / Consulado de comercio / Comerciantes / Cabildo / Reformas borbónicas.

- "Capital comercial y producción agrícola: Nueva España y la Audiencia de Quito en el siglo XVIII”, AEA, 1989, tomo XLVI, págs. 131-172.

Nueva España / Quito / Haciendas / Comerciantes / Cabildo.

Brading, David A.: "Gobierno y élite en el México colonial durante el siglo XVIII”, HM, 1974, tomo XXIV, n. 4 (92), págs. 611-645.

Minería / Comerciantes / Aristocracia / Administración colonial.

- Mineros y comerciantes en el México borbónico (1763-1810), México, FCE, 1975 (Cambridge University Press, 1971), 497 págs.

Reformas borbónicas / Élites / Poder político / Cabildo / Minería / Comerciantes / Aristocracia / Títulos nobiliarios / Zacatecas / Guanajuato.

Calvo, Thomas: Poder, religión y sociedad en la Guadalajara del siglo XVII, Mexico, CEMCA / Ayuntamiento de Guadalajara, 1992, 423 págs.

Nueva Galicia / Audiencia / Clases sociales / Hacendados / Poder político / Iglesia / Familia / siglo XVII.

Carreño, Alberto María: "Opulencia y pobreza de Borda”, Memorias de la Academia Mexicana de la Historia, octubre-diciembre 1962, tomo XXI, n. ${ }^{\circ}$, págs. 333-353.

Nueva España / Zacatecas / Taxco / Plata (minería de la) / Élite / Minería colonial / siglos XVIII / Emigración.

Castañeda, Carmen, ed.: Élite, Clases sociales y rebelión en Guadalajara y Jalisco, siglos XVIII y XIX, Guadalajara, El Colegio de Jalisco / Gobierno de Jalisco, 1988, 130 págs.

Nueva Galicia / Siglos XVIII-XIX / Independencia / Élites / Universidad / Clases sociales.

Castañeda, Carmen: La educación en Guadalajara durante la Colonia 1552-1821, Guadalajara, El Colegio de Jalisco / El Colegio de México, 1984, 513 págs.

Guadalajara / Nueva Galicia / Universidad / Siglos XVI-XVIII / Élites / Hacendados / Independencia. 
- "Una élite de Guadalajara y su participación en la Independencia", Encuentro, 1985, n. ${ }^{\circ}$ 8, págs. 39-58. Guadalajara / Nueva Galicia / Universidad / Élites / Hacendados / Independencia.

Cayetano Reyes, G.: "Expósitos e hidalgos. La polarización social de la Nueva España”, Boletín del AGN, abril-junio de 1981, 3. a série, tomo V, n. ${ }^{\circ} 16$, págs. 3-5.

Fuentes / Estructura social / Nueva España / siglos XVI-XVIII / Hidalguía / Nobleza / Caridad / Infancia.

Chavot, Frederick C.: "Los poderosos Aguayo", en Anales del Museo Nacional de Arqueología, Historia y Etnografía, México, Tomo VII, cuarta época, págs. 127-146.

Nueva España / siglos XVI-XVIII / Estructura social / Propiedades (grandes / Haciendas / Nobleza / Élites / Sonora / Coahuila / Nuevo León / Provincias Internas / Familias (grandes).

Chevalier, François: La formation des grands domaines au Mexique. Terre et société aux XVIe-XVIIe siècles, Paris, Institut d'Ethnologie, 1952, XXVII480 págs. (Trad. FCE 1976: La formación de los latifundios en México).

Nueva Galicia / Siglos XVI-XVII / Audiencia / Guadalajara / Zacatecas / Haciendas / Terratenientes / Títulos nobiliarios / Frontera / Mentalidades.

Comerciantes mexicanos en el siglo XVIII, selección de documentos e introducción por Carmen Yuste, México, UNAM, 1991, 265 págs.

Documentos / Veracruz / Filipinas / Ciudad de México / Consulado de México / Comerciantes (grandes) / Empresarios / Flotas / Milicias / Ferias / Alcabalas / Cádiz / Acapulco / Perú (comercio con el).

Couturier, Edith: "Pedro Romero de Terreros: ¿comerciante o empresario capitalista del siglo XVIII?" en Florescano, E., Coord.: Orígenes y desarrollo de la burguesía en América Latina, 1700-1955. México, Nueva Imagen, 1985.

Empresarios / Aristocracia / Comerciante / Banco de plata / Aguardiente / Emigración / Andalucía / Haciendas / Trabajadores de minas / Jesuitas / Minería de plata / Aviadores / Real del Monte / Pachuca / Títulos nobiliarios / Pulque.

- "Una viuda aristocrática en la Nueva España del siglo XVIII: la Condesa de Miravalle", HM, enero-marzo de 1992, tomo XLI, núm. 3 (163), págs. 327-364.

Nueva España / siglo XVIII / Estructura social / Propiedades (grandes) / Haciendas / Nobleza / Mujeres / Ciudad de México / Familias (grandes).

Familias novohispanas. Siglos XVI al XIX, coord. Pilar Gonzalbo, México, El Colegio de México, 1991, 400 págs.

América / Nueva España / siglos XVI-XVIII / Empresarios / Aristocracia / Comerciantes / Emigración / Haciendas / Títulos nobiliarios / Mujeres / Caridad.

Fernández de Recas, Guillermo: Mayorazgos de la Nueva España, Mexico, Instituto Bibliográfico Mexicano, 1968, 509 págs.

Nueva España / Conquistadores / Haciendas / Propiedad (gran) / siglos XVI-XVII / Nobleza. 
Ganster, Paul: "La familia Gómez de Cervantes. Linaje y sociedad en el México colonial", $H M$, octubre-diciembre de 1981, vol. 31, n. ${ }^{\circ} 2$, págs. 197-232.

Estructura social / Nobleza / Mentalidades / Haciendas / Linajes.

Garavaglia, Juan Carlos; Grosso, Juan Carlos: "Mexican Elites of a Provincial Town: The Landowners of Tepeaca (1700-1870)", HAHR, 1990, tomo 70, n. ${ }^{\circ}$ 2, págs. 255-293.

Nueva España / Puebla / siglos XVIII-XIX / Hacendados / Tierra / Comercio.

García Bernal, Manuela Cristina: "La aristocracia de Yucatán (siglo XVII)", en América: encuentro y asimilación, Actas de las Segundas jornadas de historiadores americanistas (oct. 1988), Granada, 1989, págs. 317-331.

Yucatán / Siglo XVIII / Hacendados / Tierra.

González Muñoz, Victoria: Cabildos y grupos de poder en Yucatán (siglo XVII), Sevilla, Publicaciones de la Excma. Diputación de Sevilla, 1994, 372 págs.

Yucatán / Siglo XVII / Hacendados / Tierra / Cabildo / Comercio.

González Polo, Ignacio: El palacio de los condes de Santiago de Calimaya (Museo de la Ciudad de México), México, Colección Distrito Federal, 1983, 148 págs.

Aristocracia / Títulos nobiliarios / siglos XVII-XVIII / Ciudad de México / Arte colonial.

Gutiérrez, Ramón A.: When Jesus came, the Corn Mothers went away: Marriage, Sexuality and power in New Mexico, 1500-1846, Palo Alto, Stanford University Press, 1991.

Nuevo México / siglos XVI-XIX / Aristocracia / Familias (grandes) / Haciendas / Mentalidades.

Hamnett, Brian: "Social Structure and Regional Elites in Late Colonial Mexico, 1750-1824", University of Glasgow, Institute of Latin American Studies, Occasional Papers, 1984, n. ${ }^{\circ}$ 41, 32 págs.

Nueva España / siglos XVII-XVIII / Regiones / Estructura social / Élites / Aristocracia / Haciendas / Comercio.

Hoberman, Louisa: Mexico's Merchant Elite, 1590-1660. Silver, State and Society, Durham / London, Duke University Press, 1991, XIV-352 págs.

Ciudad de México / Comerciantes / siglos XVI-XVII / Conquistadores / Consulado de comercio / Familias (grandes).

Kicza, John E.: "The Great Families of Mexico: Elite Maintenance and Business Practices in Late colonial Mexico City", $H A H R$, 1982, tomo 62, n. ${ }^{\circ} 3$, págs. 429-456.

Ciudad de México / Comerciantes / siglo XVIII / Consulado de comercio / Familias (grandes) / Parentesco (relaciones de) / Aristocracia.

- Empresarios coloniales. Familias y negocios en la ciudad de México durante los Borbones, México, FCE, 1986, 285 págs. (Colonial Entrepreneurs. 
Families and Business in Bourbon Mexico City, Albuquerque, University of New Mexico Press, 1983).

Ciudad de México / Comerciantes / siglos XVIII / Consulado de comercio / Familias (grandes) / Parentesco (relaciones de) / Aristocracia.

- "Mexican Merchants and their Links to Spain, 1750-1850", A Paper for the Session "Spain and America: Conflict, Transition and Continuity, 17501850", in K. Andrien y L. Johnson, eds.: The Political Economy of Spanish America in the Age of Revolution, 1750-1850, Albuquerque, University of New Mexico Press, 1994, págs. 115-136.

Ciudad de México / Comerciantes / siglos XVIII-XIX / Independencia / Consulado de comercio / Familias (grandes) / Inmigración / España / Parentesco (relaciones de) / Aristocracia.

— "La familia Iturbe e Iraeta en la época de la Independencia mexicana", en $L a$ familia en el mundo iberoamericano, Pilar Gonzalbo Aizpuru y Cecilia Rabell, comp., México, UNAM / Instituto de Investigaciones Sociales, 1994, págs. 417-440.

Ciudad de México / Comerciantes / siglos XVIII-XIX / Independencia / Consulado de comercio / Familias (grandes) / Inmigración / España / Parentesco (relaciones de) / Aristocracia / Cofradías.

- "Spanish Inmigrants in the Americas in the Bourbon Era: Social Integration, Political Participation and the Origins of the Independence Movement", in Colonial Latin American Review, 1995 (à paraître).

Ciudad de México / Comerciantes / siglos XVIII-XIX / Independencia / Consulado de comercio / Familias (grandes) / Inmigración / España / Parentesco (relaciones de) / Aristocracia.

Ladd, Doris: The Mexican Nobility at Independence, 1780-1826, Austin, University of Texas, Institute of Latin American Studies, 1976, 316 págs. (trad. FCE, 1986).

Nueva España / Aristocracia / Títulos nobiliarios / Militares (Ordenes) / Haciendas / Propiedad (gran) / Mayorazgos / Minería de la plata / Cofradías / Mentalidades / Independencia / Familias (grandes).

Langue, Frédérique: "Del minero rico a la nobleza: el papel de la frontera zacatecana en la formación de una élite económica y social", $A E A, 1987$, tomo XLIV, págs. 173-193.

Nueva España / Zacatecas / siglo XVIII / Nobleza / Títulos nobiliarios / Militares (Ordenes) / Haciendas / Mayorazgos / Minería de la plata / Mentalidades / Rebeliones / Frontera (zona de).

- "La convergencia de los intereses particulares y estatales: el alboroto de 1767 en Nueva Galicia”, Temas Americanistas, 1990, n. ${ }^{\circ}$, págs. 14-17.

Nueva España / Zacatecas / siglo XVIII / Nobleza / Títulos nobiliarios / Militares (Ordenes) / Haciendas / Mayorazgos / Salinas / Mentalidades / Rebeliones / Jesuitas (expulsión de los) / Gálvez (José de). 
- "Mineros y poder en Nueva España. El caso de Zacatecas en vísperas de la independencia”, RI, 1991, vol. LI, núm. 192, págs. 327-341.

Nueva España / Zacatecas / Ciudad de México / siglo XVIII / Estructura social / Economía / Haciendas / Propiedad (gran) / Minería de la plata / Tribunal de Minería / Consulados de comercio / Comerciantes / Mentalidades / Familias (grandes) / Independencia.

- Mines, terres et société à Zacatecas (Mexique) de la fin du XVIe siècle à l'Indépendance, París, Publications de la Sorbonne, 1992, 445 págs.

Nueva España / Zacatecas / siglos XVII-XVIII / Estructura social / Economía / Nobleza / Títulos nobiliarios / Militares (Ordenes) / Haciendas / Mayorazgos / Propiedad (gran) / Minería de la plata / Mentalidades / Frontera (zona de) / Familias (grandes).

- "De la munificence à l'ostentation. Attitudes et modèles culturels de la noblesse de Mexico (XVIIIe siècle)”, Caravelle, 1995, n. ${ }^{\circ}$ 64, págs. 49-75.

Nueva España / Ciudad de México / siglos XVII-XVIII / Estructura social / Nobleza / Artes / Arquitectura / Fiestas / Mentalidades / Cofradías.

Lavrin, Asunción: "El capital eclesiástico y las élites sociales en Nueva España a fines del siglo XVIII", Mexican Studies / Estudios Mexicanos, 1985, vol. I, n. ${ }^{\circ} 1$.

Haciendas / Censos / Vales Reales (Decreto de consolidación de) / Cofradías / Inquisición (Tribunal de la ) / Cuautitlán / Pachuca / Tlaxcala / Querétaro / Zacatecas / Consulado / Aristocracia / Ordenes religiosas.

— "Dowries and Wills: a View of Women's Socioeconomic Roles in Colonial Guadalajara and Puebla, 1640-1790", HAHR, may 1979, tomo 59, n. ${ }^{\circ} 2$, págs. 280-304.

Nueva España / Estructura social / siglos XVII-XVIII / Guadalajara / Puebla / Haciendas / Censos / / Aristocracia / Ordenes religiosas / Mujeres / Familias (grandes).

Liehr, Reinhard: Ayuntamiento y oligarquía en Puebla 1687-1810, 2 vols., Mexico, Sepsetentas, 1976, núms. 242-243.

Nueva España / Puebla / siglos XVII-XVIII / Cabildo / Oligarquía / Hacendados.

Lindley, Richard: Las haciendas y el desarrollo económico. Guadalajara, México, en la época de la Independencia, México, FCE, 1987, 176 págs.

Nueva España / Guadalajara / siglo XVIII / Independencia / Haciendas / Propiedad (gran) / Nobleza / Comercio.

Loreto López, Rosalva: "Familias y conventos en Puebla de los Angeles durante las reformas borbónicas: los cambios del siglo XVIII", Anuario de IEHS, 1990, vol. V.

Puebla / siglos XVIII / Ordenes religiosas / Familias (grandes) / Élites / Reformas borbónicas.

McCaa, Robert: "Calidad, Clase, and Marriage in Colonial Mexico: The Case of Parral, 1788-90”, HAHR, 1984, tomo 64, n. 3 3, págs. 477-501.

Nueva España / Clases sociales / Castas / Matrimonio / Parral. 
Martínez Cosío, Leopoldo: Los caballeros de las órdenes militares en México, Mexico, Ed. Santiago, 1946, 353 págs.

Nueva España / siglos XVI-XVIII / Nobleza / Militares (Ordenes).

Meissner, Jochen: Eine Elite im Umbruch. Der Stadtrat von Mexiko zwischen kolonialer Ordnung und unabhängigem Staat (1761-1821), Stuttgart, Franz Steiner Verlag, 1993, 424 págs.

Ciudad de México / Siglos XVIII-XIX / Cabildo Independencia / Familias (grandes) / Administración colonial / Élite "proto-nacional" / 1808 / Cortes de Cádiz.

O'Gorman, Edmundo: "La nobleza colonial. Ultimo tercio del siglo XVIII", Boletín del Archivo General de la Nación, 1942-1943, tomo 13, n. 4 (octubre-diciembre), tomo 14, n. $^{\circ} 2$ (abril-junio), tomo 14, n. $^{\circ} 3$ (julio-septiembre).

Nobleza / Títulos nobiliarios / Haciendas / Minería / Comercio.

Ortega y Pérez Gallardo, Ricardo: Historia genealógica de las familias más antiguas de México, México, A. Carranza, 1908, 3 vols.

Nueva España / siglos XVI-XVIII / Nobleza / Títulos nobiliarios / Militares (Ordenes).

Peña, José Francisco de la: Oligarquía y propiedad en Nueva España (1550-1624), México, FCE, 1983, 306 págs.

Nueva España / siglos XVI-XVII / Propiedad (gran) / Haciendas / Oligarquía / Aristocracia.

Pérez Herrero, Pedro: "Los beneficiarios del reformismo borbónico: metrópoli versus élites novohispanas", HM, octubre-diciembre de 1991, tomo XLI, núm. 2 (162), págs. 207-264.

Nueva España / Ciudad de México / Siglo XVIII / Reformas Borbónicas / Élites / Comerciantes.

Ruiz Medrano, Ethelia: Gobierno y sociedad en Nueva España: la segunda Audiencia y Antonio de Mendoza, México, El Colegio de Michoacán / Gobierno del Estado de Michoacán, 1991, 407 págs.

Nueva España / Siglo XVI / Virreyes / Audiencias / Administración colonial / Nobleza.

Sánchez, Evelyne: Les élites de Puebla de 1786 à 1847. Définitions et stratégies des élites principales et secondes; sources et méthodes, Université de Toulouse-Le Mirail / IPEALT, Mémoire de DEA, 1994, 162 págs.

Fuentes / Puebla / Siglos XVIII-XIX / Independencia / Nobleza / Comerciantes / Obrajes / Haciendas.

Schell, William J.: Medieval Iberian Tradition and the Development of the Mexican Hacienda, Syracuse University, Maxwell School of Citizenship and Public Affairs, Foreign and Comparative Studies / Latin American Studies n. ${ }^{\circ} 8,1986,117$ págs.

Nueva España / siglos XVI-XVIII / Propiedad (gran) / Haciendas / Aristocracia / Mentalidades. 
Schwaller, J.F.: "Tres familias mexicanas del siglo XVI", $H M$, octubre-diciembre de 1981, tomo XXX, n. ${ }^{\circ}$ 2, págs. 171-208.

Nobleza / Nueva España / Inmigración / Iglesia / Conquistadores / Mayorazgo / Familia / Ciudad de México / Michoacán / Puebla / Florida / Cuba / Sevilla / Encomiendas / Ejército.

— “Élites in New Spain”, LARR, 1986, tomo XXI, n. o 2, págs. 189-196.

Nueva España / Siglos XVI-XVIII / Audiencia de Nueva Galicia / Guadalajara / Censos / Haciendas / Independencia / Oligarquía / Ciudad de México / Cabildo.

Serrera Contreras, Ramón María: Guadalajara ganadera. Estudio regional novohispano 1760-1805, Sevilla, EEHA, 1977, XII-458 págs.

Nueva España / Guadalajara / siglo XVIII / Cajas reales / Haciendas / Nobleza / Propiedad (gran).

Taylor, William B.: Landlord and Peasant in Colonial Oaxaca, Stanford, University Press, 1972, 285 págs.

Aristocracia / Latinfundios / Oaxaca / Puebla / Morelos / Tabasco / Chiapas / Yucatán / Guatemala / Encomiendas / Tierras (Composiciones de) / Conquistadores / Hidalguía / Mano de obra / Indígenas (comunidades) / Caciques / Mayas / Indios (corregidores de).

- "Landed Society in New Spain: A View from the South", HAHR, August, 1974, tomo 54, n. ${ }^{\circ}$ 3, págs. 387-413.

Aristocracia / Latifundios / Oaxaca / Puebla / Morelos / Tabasco / Chiapas / Yucatán / Guatemala / Encomiendas / Tierras (Composiciones de) / Conquistadores / Hidalguía / Indígenas (comunidades) / Caciques / Mayas / Indios (corregidores de).

Torales Pacheco, María Cristina: “Tradicionalismo y modernidad en el comercio novohispano de la segunda mitad del siglo XVIII: la Compañía de Francisco Ignacio de Yraeta", en A. Ouweneel y M.C. Torales Pacheco, comps.: Empresarios, indios y estado. Perfil de la economía mexicana (siglo XVIII), Amsterdam, CLA / CEDLA, Latin American Studies n. ${ }^{\circ} 45$, 1988, págs. 58-70.

Nueva España / España / siglo XVIII / Relaciones comerciales / Comerciantes / Comercio (compañías de) / Consulados de comercio / Ciudad de México / Filipinas / Acapulco / Veracruz / Compañía de Filipinas (Real) / Vascos / Matrimonio / Cabildo / Casa de moneda / Mentalidades.

Tutino, John: "Hacienda Social Relations in Mexico: The Chalco Region in the Era of Independence”, HAHR, 1975, tomo 55, n. ${ }^{\circ} 3$, págs. 496-528.

Nueva España / siglo XVIII / Haciendas / Ciudad de México / Chalco / Indios / Pueblos (de indios) / Conventos / Temporalidades / Oligarquía / Títulos nobiliarios / Censos / Familia / Mano de obra.

- Creole Mexico: Spanish Elites, Haciendas and Indian Towns 1750-1810, Austin, University of Texas, 1976; Ann Arbor, University Microfilms, 1978, 446 págs.

Nueva España / siglo XVIII / Élite secundaria / Haciendas / Peninsulares / Criollos / Ciudad de México / Chalco / Indios / Pueblos (de indios) / Conventos / Temporalidades / Oligarquía / Títulos nobiliarios / Censos / Familia / Mano de obra. 
- "Power, Class and Family: Men and Women in the Mexican Elite, 17501810", The Americas, 1983, n. ${ }^{\circ} 39$, págs. 359-381.

Nueva España / siglo XVIII / Haciendas / Poder político / Ciudad de México / Oligarquía / Comerciantes / Títulos nobiliarios / Censos / Familia / Mano de obra.

Vargas-Lobsinger, María: "El ascenso social de los inmigrantes españoles: el caso de Francisco de Valdivieso (1683-1743)", HM, abril-junio de 1986, vol. XXV, n. ${ }^{\circ}$ (140), págs. 601-619.

Nueva Vizcaya / Siglo XVII-XVIII / Inmigración / Vascos / Nobleza / Títulos nobiliarios / Comerciantes / Hacendados / Minería / Banco de plata / Mayorazgos.

- Formación y decadencia de una fortuna. Los mayorazgos de San Miguel de Aguayo y de San Pedro del Alamo, 1583-1823, México, UNAM, 1992, 237 págs.

Nueva Vizcaya / Ciudad de México / Siglos XVI-XIX / Inmigración / Vascos / Frontera (zona de) / Nobleza / Títulos nobiliarios / Comerciantes / Hacendados / Minería / Banco de plata / Mayorazgos / Vales reales (Consolidación de ) / Independencia.

Velázquez, María del Carmen: "En pos del marqués de Altamira", Diálogos, México, enero de 1975, núm. 61.

Sonora / Coahuila / Provincias Internas / Siglo XVIII / Frontera (zona de) / Nobleza / Títulos nobiliarios / Hacendados.

— “Encontré al marqués de Altamira?”, Diálogos, México, septiembre de 1975, núm. 65.

Sonora / Coahuila / Provincias Internas / Siglo XVIII / Frontera (zona de) / Nobleza / Títulos nobiliarios / Hacendados.

- El marqués de Altamira y las Provincias Internas de Nueva España, México, El Colegio de México, 1976.

Yuste, Carmen: "Francisco Ignacio de Yraeta y el comercio transpacífico", Estudios de Historia novohispana, 1987, n. ${ }^{\circ}$ 9, págs. 189-217.

Nueva España / España / siglo XVIII / Relaciones comerciales / Comerciantes / Comercio (compañías de) / Consulados de comercio / Ciudad de México / Filipinas / Acapulco / Compañía de Filipinas (Real) / Vascos.

\section{Nueva Granada}

Colmenares, Germán: Cali: terratenientes, mineros y comerciantes siglo XVIII, Cali, Universidad del Valle, 1975, 263 págs.

Nueva Granada / Chocó / Cali / Minería del oro / Haciendas / Comerciantes / Cabildo / Parentesco.

McFarlane, Anthony: "Comerciantes y monopolio en la Nueva Granada. El Consulado de Cartagena de Indias”, Anuario Colombiano de Historia Social y de la Cultura, 1983, núm. 11.

Nueva Granada / Cartagena / siglo XVIII / Reformas borbónicas / Consulado de comercio / Comerciantes. 
Marzahl, Peter: "Creoles and Government: The Cabildo of Popayán", HAHR, 1974, tomo 54, n. ${ }^{\circ} 4$, págs. 636-656.

Administración colonial / Cabildo / Élite / Criollos / Político (Poder) / Popayán / Minería.

Ruiz Rivera, Julián B.: "El juez Villabona frente a la oligarquía encomendera de Cartagena", AEA, 1995, tomo LII-1, págs. 91-116.

Audiencia de Santa Fe / siglo XVII / Universidad (Sevilla) / Administración colonial / Ciudades / Ejército / Encomiendas / Mano de obra / Legislación / Justicia.

Stafford, Frank: "Race, Integration and Progress: Élites Attitudes and the Indian in Colombia 1750-1870", HAHR, February 91, tomo 71, n. ${ }^{\circ}$, págs. 2-33.

Nuevo Reino de Granada / Indígenas (comunidades) / Mano de obra / Haciendas / Minería / Independencia.

Twinam, Ann: "Enterprise and Élites in Eighteenth-Century Medellín", HAHR, 1979, tomo 59 , n. ${ }^{\circ}$, págs. 444-475.

Nueva Granada / Antioquia / Medellín / siglo XVIII / Minería del oro / Poder político / Élite / Cabildo / Justicia / comerciantes / Élites secundarias / Empresarios.

- Miners, Merchants and Farmers in Colonial Colombia, Austin, University of Texas Press, 1982, 193 págs.

Nueva Granada / Antioquia / Medellín / siglo XVIII / Minería del oro / Haciendas Poder político / Élite / Cabildo / Justicia / Comerciantes / Élites secundarias / Empresarios.

Uribe, María Teresa; Álvarez Gaviria, Jesús María: "El parentesco y la formación de las élites en la Provincia de Antioquia”, Estudios Sociales, 1988, 3, págs. 51-93.

Medellín / Clases sociales / Minería / Comerciantes / Hacendados / Parentesco / Familia.

Villamarín, Juan A.: "El concepto: "nobleza" en la estratificación social de Santa Fe de Bogotá en la época colonial", Estudios Andinos, vol. 8, 1978, n. ${ }^{\circ} 14$.

Nuevo Reino de Granada / Inmigración / Nobleza / títulos nobiliarios.

\section{Perú}

Balzo, Conde Bertrando Del (ed.): "Familias nobles y destacadas en el Perú en los informes secretos de un virrey napolitano (1715-1725)", Revista del Instituto Peruano de Investigaciones Genealógicas, 1965, n. ${ }^{\circ}$ 14, págs. 107-133.

Virreinato del Perú / Inmigración / Nobleza / Familias (grandes).

Bronner, Fred: "Peruvian Encomenderos in 1630: Elite Circulation and Consolidation", $H A H R$, 1977, tomo 57, n. ${ }^{\circ}$ 4, págs. 633-659.

Perú / siglos XVI-XVIII / Conquistadores / Haciendas / Propiedad (gran) / Nobleza.

- "Elite Formation in Seventeenth-Century Peru", Boletín de Estudios Latinoamericanos y del Caribe, junio de 1978, n. ${ }^{\circ}$ 24, págs. 3-26.

Perú / siglos XVI-XVIII / Conquistadores / Haciendas / Propiedad (gran) / Nobleza. 
Brownrigg, Leslie Ann: "Areas y mecanismos de control de la élite regional”, Estudios Andinos, 1978, vol. 8, n. ${ }^{\circ} 14$.

Perú / siglos XVI-XVIII / Conquistadores / Haciendas / Propiedad (gran) / Nobleza.

Burkholder, Mark A.: "From Creole to Peninsular: The Transformation of the Audiencia of Lima", HAHR, 1972, tomo 52, n. 3 3, págs. 395-415.

Perú / siglos XVI-XVIII / Conquistadores / Haciendas / Administración colonial / Audiencias / Nobleza.

- y Chandler, D.S.: De la impotencia a la autoridad. La Corona española y las Audiencias en América, 1687-1808. México, FCE, 1984, 475 págs.

Perú / siglos XVI-XVIII / Conquistadores / Haciendas / Administración colonial / Audiencias / Nobleza.

Cahill, David P.: "Repartos ilícitos y familias principales en el sur andino: 17801824”, RI, 1988, tomo XLVIII, núms. 182-183, págs. 449-473.

Perú / siglos XVIII-XIX / Haciendas / Comercio / Familias (grandes).

Campbell, Leon G.: "A Colonial Establishment: Creole Domination of the Audiencia of Lima During the Late Eighteenth Century", $H A H R$, February 1972, tomo 52, n. ${ }^{\circ}$, págs. 1-25.

Perú / siglos XVI-XVIII / Conquistadores / Haciendas / Administración colonial / Audiencias / Nobleza.

Davies, Keith A.: Landowners in Colonial Peru, Austin, University of Texas Press, 1987.

Perú / siglos XVIII-XIX / Haciendas / Encomienda / Propiedad (gran) / Comercio / Familias (grandes) / Parentesco (relaciones de).

Flores Galindo, Alberto: Aristocracia y plebe: Lima 1760-1830, Lima, Mosca Azul Editores, 1984, 270 págs.

Perú / Lima / siglos XVIII-XIX / Haciendas / Comercio / Familias (grandes).

García Vera, José Antonio: Los comerciantes trujillanos (1780-1840), Lima, Artex Editores, 1989.

Perú / siglos XVIII-XIX / Trujillo / Haciendas / Comercio / Familias (grandes).

Hampe Martínez, Teodoro: "Sobre encomenderos y repartimientos en la diócesis de Lima a principios del siglo XVII", JGSWGLA, 1986, Band 23, págs. 121-144.

Perú / siglo XVI / Haciendas / Encomienda / Familias (grandes) / Repartimientos.

Jensen de Sousa Foronda, J.: "Los Ortiz de Foronda" en Apuntes para el estudio genealógico de familias limeñas de los siglos XVII y XVIII, 1989, N. ${ }^{\circ} 1$.

Perú / siglos XVII-XIX / Haciendas / Comercio / Familias (grandes) / Parentesco (relaciones de).

Klein, Herbert S.: “The Structure of the Hacendado Class in Late Eighteenth Century Alto Peru: The Intendencia de La Paz", HAHR, 1980, tomo 60, n. ${ }^{\circ} 2$, págs. 191-212.

Perú / siglos XVIII-XIX / La Paz / Estructura social / Haciendas / Comercio / Familias (grandes) / Nobleza. 
Lasarte Ferreyros, Luis: Familias establecidas en el Perú durante la Conquista y el Virreinato, Lima, Imprenta Aguirre, 1938.

Perú / siglos XVII-XIX / Haciendas / Comercio / Familias (grandes) / Parentesco (relaciones de).

Lavallé, Bernard: El mercader y el marqués 1700-1730, Lima, Editorial Banco Central de Reserva del Perú, 1987.

Perú / siglos XVII-XIX / Haciendas / Comercio / Títulos nobiliarios / / Familias (grandes) / Parentesco (relaciones de) / Mentalidades.

Lockhardt, James: Spanish Peru 1532-1560. A Colonial Society, Madison, The University of Wisconsin Press, 1968, XI-285 págs.

Perú / siglo XVI / Haciendas / Encomienda / Familias (grandes) / Repartimientos.

- Men of Cajamarca: A Social and Biographical Study of the First Conquerors of Peru, Austin, University of Texas Press, 1972.

Perú / siglo XVI / Conquistadores / Encmiendas / Haciendas / Encomienda / Familias (grandes) / Repartimientos.

Lohmann Villena, Guillermo: Los comerciantes vascos en el Virreinato peruano, Separata, Bilbao, Cámara de Comercio, 1988.

Perú / siglos XVII-XVIII / Inmigración / Vascos / Haciendas / Familias (grandes) Parentesco (relaciones de).

López Beltrán, Clara: "Intereses y pasiones de los vecinos de La Paz en el siglo XVII. LA élite provinciana en Charcas, virreinato del Perú", AEA, 1995, tomo LII-1, págs. 35-56.

Virreinato del Perú / Siglo XVII / Hacendados / Empresarios / Poder político / Familia / Conquistadores / Parentesco.

Mazzeo, Cristina: Las estrategias de un mercader criollo peruano en el marco del comercio libre. José de Lavalle y Cortés, Conde de Premio Real 1777-1815, Lima, Pontificia Universidad Católica del Perú, 1992, 238 págs.

Siglos XVIII-XIX / Comerciantes / Política / Reformas borbónicas / Mentalidades / Aristocracia / Élite / Hidalguía / Lima / Buenos Aires / Milicias / Consulado / Inmigración / Linajes / Hacendados / Emancipación.

- "Tradición o modernidad en el comerciante peruano a fines del XVIII. Un estudio comparativo", ponencia presentada en el Coloquio Internacional "Historia, cultura e identidades latinoamericanas", Universidad de Lima, 31 de agosto - 3 de septiembre de 1993.

Siglos XVIII-XIX / Comerciantes / Política / Reformas borbónicas / Mentalidades / Aristocracia / Élite / Hidalguía / Lima / Buenos Aires / Milicias / Consulado / Inmigración / Linajes / Hacendados / Emancipación.

- El comercio libre en el Perú. Las estrategias de un comerciante criollo José Antonio de Lavalle y Cortés 1777-1815, Lima, Pontificia Universidad Católica del Perú / Fondo editorial, 1994, 279 págs.

Comerciantes / Política / Reformas borbónicas / Mentalidades / Aristocracia / Élite / Hidalguía / Lima / Buenos Aires / Milicias / Consulado / Inmigración / Linajes / Hacendados / Emancipación. 
O'Phelan Godoy, Scarlett: “Aduanas, mercado interno y élite comercial en el Cusco antes y después de la gran rebelión de 1780", Apuntes, Revista de Ciencias Sociales, Universidad del Pacífico, segundo semestre de 1986, n. ${ }^{\circ} 19$, págs. 53-72.

Siglo XVIII / Comerciantes / Política / Reformas borbónicas / Mentalidades / Repartimientos / Aristocracia / Élite / Cuzco / Hacendados / Rebeliones.

Ramírez, Susan E.: Patriarcas provinciales. La tenencia de la tierra y la economía del poder en el Perú colonial, Madrid, Alianza América, 1991 (University of New Mexico Press, 1986), 378 págs.

Virreinato del Perú / Aristocracia / Linajes / Encomienda / Hacendados / Lambayeque.

- "Instability at the Top: A Social History of the Landed Élite in Colonial Peru”, Colonial Latin American Historical Review, Summer 1994, Vol. 3, n. ${ }^{\circ}$, págs. 329-346.

Virreinato del Perú / Aristocracia / Linajes / Encomienda / Hacendados / Lambayeque.

Rizo-Patrón, Paul: "La familia noble en la Lima borbónica: patrones matrimoniales y dotales", Boletín del Instituto Riva-Agüero, 1989, n. ${ }^{\circ}$ 16, págs. 265-302.

Aristocracia / siglos XVIII-XIX / Nobleza / Hidalguía / Títulos nobiliarios / Ordenes militares / Criollos / Familia / Reformas Borbónicas / Matrimonio / Mentalidades.

- "La nobleza en Lima en tiempos de los Borbones", Bulletin de l'Institut Français d'Etudes Andines, 1990, tomo 19, n. ${ }^{\circ}$ 1, págs. 129-163.

Perú (Virreinato del) / Aristocracia / siglo XVIII (1700-1821) / Nobleza / Hidalguía / Títulos nobiliarios / Ordenes militares / Criollos / Familia / Reformas Borbónicas / Mentalidades.

\section{Puerto Rico}

Cubano Iguina, Astrid: "El estudio de las élites económicas y la política en Puerto Rico en el siglo XIX", Boletín del Centro de Investigaciones Históricas, 1988-1989, núm. 4.

Puerto Rico / siglo XIX / Haciendas / Familias (grandes).

Flores Collazo, María Margarita: "Vulnerabilidad económica y política de la élite criolla del Puerto Rico del siglo XIX”, Secuencia, mayo-agosto de 1994, n. ${ }^{\circ}$ 29, págs. 171-190.

Puerto Rico / siglo XIX / Haciendas / Familias (grandes).

Navarro García, Jesús Raúl: “Grupos de poder y tensiones sociales en Puerto Rico durante la crisis del Imperio (1815-1837): un intento de síntesis”, AEA, 1993, tomo L-1, págs. 133-162.

Puerto Rico / siglo XIX / Haciendas / Familias (grandes) / Política. 
FRÉDÉRIQUE LANGUE

\section{Río de la Plata}

Ansaldi, Waldo: "La burguesía comercial de Buenos Aires en el siglo XVIII", en Florescano, E., coord.: Orígenes y desarrollo de la Burguesía en América Latina, 1700-1955.

Río de la Plata / siglos XVIII / Comerciantes / Consulado de comercio / Burguesía.

Ferreiro, Juan Pablo: "Tierras, encomiendas y élites. El caso de Jujuy en el siglo XVII”, AEA (Historiografía y bibliografía), 1995, tomo LII-1, págs. 189-214. Río de la Plata / Jujuy / siglo XVII / Tierra / Haciendas / Encomienda.

Gelman, Jorge: "Economía natural y economía monetaria: los grupos dirigentes de Buenos Aires a principios del siglo XVIII”, AEA, 1987, tomo XLIV, págs. 89-107.

Río de la Plata / siglo XVIII / Comerciantes / Economía / Burguesía.

- "El gran comerciante y el sentido de la circulación monetaria en el Río de la Plata colonial tardío", Revista de Historia Económica, 1987, vol. 5, n. ${ }^{\circ} 3$. Río de la Plata / siglo XVIII / Comerciantes / Economía / Burguesía.

- "Sobre el carácter del comercio colonial y los patrones de inversión de un gran comerciante en el Río de la Plata del siglo XVIII", Boletín del Instituto de Historia Argentina y Americana "Dr. E. Ravignani", 1989, 3ra serie, n. ${ }^{\circ} 1,1 \mathrm{r}$ semestre.

Río de la Plata / siglo XVIII / Comerciantes / Economía / Burguesía.

González Rodríguez, Adolfo Luis: "El Cabildo de Córdoba durante el siglo XVI: encomenderos, propietarios de tierras, tratantes de negros y comerciantes. Análisis de un grupo de poder", Estudios de Historia Social y Económica de América, 1988, núms. 3-4, págs. 29-45.

Río de la Plata / Córdoba / siglo XVI / Haciendas / Encomiendas / Mano de obra / Comerciantes / Economía / Burguesía.

Mariluz Urquijo, José María: "Solidaridades y antagonismos de los comerciantes de Buenos Aires a mediados del setecientos", Investigaciones y ensayos, 1987, n. ${ }^{\circ} 35$, págs. 47-83.

Río de la Plata / siglo XVIII / Comerciantes / Economía / Burguesía / Parentesco (relaciones de).

Mayo, Carlos A.: "Landed but no Powerful: the Colonial Estancieros of Buenos Aires", HAHR, November 1991, tomo 71, n. 4.

Río de la Plata / siglo XVIII / Haciendas / Tierra.

Moutoukias, Zacharias: "Power, Corruption and Commerce: The Making of the local Administrative Structure in Seventeenth-Century Buenos Aires", HAHR, 1988, tomo 68, n. ${ }^{\circ}$, págs. 771-801.

Administración / Fiscalidad / Fraude / Comerciantes / Río de la Plata / Buenos Aires / Redes / Familia / Alto Perú / Mentalidades / Consulado. 
— "Réseaux personnels et autorités coloniales: les négociants de Buenos Aires au XVIIIe siècle”, AESC, juillet-octobre 1992, núms. 4-5, págs. 889-915.

Administración / Fiscalidad / Fraude / Comerciantes / Río de la Plata / Buenos Aires / Redes / Familia / Alto Perú / Mentalidades / Consulado.

Peire, Jaime: "La manipulación de los capítulos provinciales, las élites y el imaginario sociopolítico colonial tardío", $A E A, 1993$, tomo L, n. ${ }^{\circ}$, págs. 11-54.

Río de la Plata / Buenos Aires / Cabildos / Élites / Independencia / Poder político / Ideas (historia de las).

Saguier, Eduardo E.: "La corrupción administrativa como mecanismo de acumulación y engendrador de una burguesía comercial local”, $A E A, 1989$, tomo XLVI, págs. 269-303.

Administración colonial / Fiscalidad / Fraude / Comerciantes / Río de la Plata / Buenos Aires / Redes / Familia / Mentalidades / Consulado.

- "El combate contra la "limpieza de sangre" en los orígenes de la emancipación argentina. El uso del estigma de la bastardía y el origen racial como mecanismos de defensa esgrimidos por las élites coloniales", Revista de Historia de América, julio-diciembre de 1990, n. ${ }^{\circ}$ 110, págs. 155-198.

Río de la Plata / Élites / Mentalidades / Limpieza de sangre / Independencia.

- "La lucha contra el nepotismo en los orígenes de las Reformas borbónicas. La endogamia en los cabildos de Salta y Tucumán (1760-1790)", ANDES, Antropología e Historia, 1992, n. ${ }^{\circ}$ 5, págs. 89-124.

Río de la Plata / Reformas borbónicas / Poder político / Cabildo / Élites / Mentalidades / Salta / Tucumán / Haciendas / Independencia.

— "El parentesco como herramienta de consolidación del patriciado colonial. El caso de las provincias rioplatenses del Virreinato peruano (1700-1776)", Estudios de Historia Social y Económica de América, 1993, n. ${ }^{\circ}$ 10, págs. 61-116.

Río de la Plata / Alto Perú / Élites / Mentalidades / Haciendas / Comerciantes / Parentesco / Familia / Independencia.

- "La milicia patricia y la crisis revolucionaria en el Paraguay. La Real Renta del tabaco como motor de la crisis agraria colonial", Folia Histórica del Nordeste, 1993, n. ${ }^{\circ} 11$.

Río de la Plata / Paraguay / Élites / Mentalidades / Limpieza de sangre / Milicias / Tabaco / Fiscalidad / Independencia.

- "Las contradicciones entre el fuero militar y el poder político en el Virreinato del Río de la Plata", European Review of Latin American and Caribbean Studies, June 1994, n. ${ }^{\circ}$ 56, págs. 55-73.

Nobleza / Fueros / Poder político / Río de la Plata / Milicias / Hacendados / Cosecheros. 
Socolow, Susan M.: "Marriage, Birth and Inheritance: The Merchants of Eighteenth-Century Buenos Aires", $H A H R$, 1980, tomo 60, n. ${ }^{\circ} 3$, págs. 387-406.

Buenos Aires / Élites / Comerciantes / Matrimonio / Familia / Parroquias.

Socolow, Susan: "La burguesía comerciante de Buenos Aires en el siglo XVIII", Desarrollo Económico, Buenos Aires, 1978, vol. 18, n. ${ }^{\circ}$ 70, págs. 205-216; reproducido en Orígenes y desarrollo de la burguesía en América Latina, 1985, págs. 499-514.

Río de la Plata / Siglo XVIII / Élites sociales / Comerciantes / Burguesía / Élite (secundaria) / Vascos / Migración / Criollos / Matrimonio / Propiedades urbanas / Consulado / Cabildo / Altó Perú / Chile / Tucumán / Córdoba.

- "The Economic Activities of the Porteño Merchants: The Viceregal Period", $H A H R, 1975$, tomo 55, n. $^{\circ}$ 1, págs. 1-24.

Río de la Plata / Siglo XVIII / Élites sociales / Comerciantes / Élite (secundaria) / Vascos / Migración / Criollos / Matrimonio / Consulado / Cabildo / Altó Perú / Chile / Tucumán / Córdoba.

- The Merchants of Buenos Aires, 1778-1810. Family and Commerce, Cambridge University Press, 1978.

Río de la Plata / Siglo XVIII / Élites sociales / Comerciantes / Burguesía / Élite (secundaria) / Vascos / Migración / Criollos / Matrimonio / Propiedades urbanas / Consulado / Cabildo / Altó Perú / Chile / Tucumán / Córdoba.

- The Bureaucrats of Buenos Aires, 1760-1810 : Amor al Real Servicio, Durham, Duke University Press, 1987.

Administración colonial / Legislación / Justicia / Élites / Criollos / Matrimonio.

\section{Venezuela}

Arcila Farías, Eduardo; Brito Figueroa, Federico; Maza Zavala, D.F.: "La formación de la propiedad territorial", en Estudio de Caracas, vol. II, tomo II: Historia, tecnología, economía y trabajo, 1967, págs. 927-948, "El Valle de Caracas y la formación del latifundio colonial".

Venezuela (Provincia de) / siglo XVI-XVIII / Encomienda / Haciendas / Tierra / Propiedad (gran)Aristocracia (mantuanos).

Blank, Stéphanie: "Patrons, Clients and Kin in Seventeenth Century Caracas. A Methodological Essay in Colonial Spanish Social History", HAHR, 1974, tomo 54, n. $^{\circ} 2$, págs. 258-283.

Caracas / siglo XVI-XVII / Comerciantes / Familias (grandes) / Parentesco (relaciones de).

- "Patrons, Brokers and Clients in the Families of the Elite in Colonial Caracas, 1595-1627”, The Americas, 1979, tomo XXXVI, n. ${ }^{\circ}$ 1, págs. 90-115.

Caracas / siglo XVI-XVII / Comerciantes / Familias (grandes) / Parentesco (relaciones de). 
Brito Figueroa, Federico: Historia económica y social de Venezuela, Caracas, UCV, 1974-1987, 4 vols.

Venezuela (Provincia de) / siglo XVI-XVIII / Encomienda / Haciendas / Tierra / Aristocracia (mantuanos) / Cacao.

Ferry, Robert: The Colonial Elite of Early Caracas. Formation and Crisis 15671767, Berkeley, University of California Press, 1989.

Venezuela (Provincia de) / siglos XVI-XVII / Encomienda / Haciendas / Tierra / Aristocracia (mantuanos) / Cacao / Rebeliones.

Fuentes Bajo, María Dolores: "Familia, matrimonio y poder en la Caracas colonial: el caso de los Jerez Aristeguieta, 1786-1809”, Europa e Iberoamérica. Cinco siglos de intercambios, Actas del IX Congreso Internacional de Historia de América de AHILA, Sevilla, AHILA, Junta de Andalucía, 1992, vol. I, págs. 371-389.

Venezuela (Provincia de) / siglo XVIII / Haciendas / Tierra / Aristocracia (mantuanos) / Familias (grandes) / Mujeres / Parentesco (relaciones de).

García-Baquero González, A.: "El comercio de neutrales en Venezuela (17961802). Tópico y cambio en las actitudes políticas de las élites venezolanas". $R I, 1984$, tomo XLIV, n. ${ }^{\circ} 173$, págs. 237-271.

Venezuela (Provincia de) / siglo XVIII / Comercio libre (decreto de) / Comerciantes / Aristocracia (mantuanos) / Cosecheros / Haciendas.

Iturriza Guillén, Carlos: Algunas familias caraqueñas, Caracas, 1967, 2 vols.

Venezuela (Provincia de) / siglos XVII-XVIII / Aristocracia (mantuanos) / Familias (grandes) / Parentesco (relaciones de).

Ladera, Elizabeth: Contribución al estudio de la "Aristocracia territorial" en Venezuela colonial: la familia Xerez de Aristiguieta siglo XVIII, Caracas, ANH, "Fuentes para la Historia Colonial de Venezuela", n. ${ }^{\circ} 209,1990$, 284 págs.

Venezuela (Provincia de) / siglo XVIII / Haciendas / Tierra / Aristocracia (mantuanos) / Familias (grandes) / Mujeres / Parentesco (relaciones de).

Landaeta Rosales, Manuel: "El marqués de las Riberas del Boconó y Masparro", en Tosta, Virgilio: Siete barineses ilustres, Barinas, Imprenta del Estado (Servicio de Edición y Publicación), 1988, Serie Histórica, vol. II, págs. 11-19.

Barinas (Provincia de) / siglo XVIII / Haciendas / Tierra / Aristocracia / Familias (grandes).

Langue, Frédérique: "Las élites de Venezuela y la Revolución francesa o la formación de un ideal democrático", en Aproximaciones al tema de la Revolución Francesa, coll. Separatas del Fondo Editorial de la Universidad José María Vargas, Caracas, 1990, n. ${ }^{\circ}$ 4, 23 págs.

Venezuela (Provincia de) / siglo XVIII / Haciendas / Cabildo / Aristocracia (mantuanos) / Familias (grandes) / Rebeliones / Revolución francesa / Emancipación / Independencia. 
- "Orígenes y desarrollo de una élite regional. Aristocracia y cacao en la provincia de Caracas, siglos XVI-XVIII", Tierra Firme, Caracas, abril-junio 1991, n. 34, págs. 143-161.

Venezuela (Provincia de) / siglos XVI-XVIII / Haciendas / Propiedad (gran) / Aristocracia (mantuanos) / Familias (grandes) / Comerciantes / Parentesco (relaciones de).

- "Antagonismos y solidaridades en un Cabildo colonial: Caracas, 17501810”, AEA, 1992, tomo XLIX, págs. 371-393.

Venezuela (Provincia de) / Caracas / siglos XVI-XVIII / Haciendas / Propiedad (gran) / Aristocracia (mantuanos) / Familias (grandes) / Comerciantes / Cabildo / Parentesco (relaciones de) / Criollos.

- "Desterrar el vicio y serenar las conciencias: mendicidad y pobreza en la Caracas del siglo XVIII", RI, 1994, vol. LIV, núm. 201, págs. 355-381.

Venezuela (Provincia de) / Caracas / siglo XVIII / Aristocracia (mantuanos) / Cabildo / Ordenes religiosas / Mentalidades.

- "La representación venezolana en las Cortes de Cádiz: José Domingo Rus", Boletín Americanista, 1995, n. ${ }^{\circ}$ 45, año XXXV, págs. 221-247.

Venezuela (Provincia de) / Maracaibo / siglo XVIII / Política / Cortes de Cádiz / Emancipación / Independencia.

- "El círculo de las alianzas. Estructuras familiares y estrategias económicas de la élite mantuana (siglo XVII)", Bol. ANH, enero-marzo de 1995, n. ${ }^{\circ} 309$, págs. 97-121.

Venezuela (Provincia de) / Caracas / siglos XVI-XVIII / Haciendas / Propiedad (gran) / Aristocracia (mantuanos) / Familias (grandes) / Comerciantes / Cabildo / Parentesco (relaciones de) / Criollos.

López Bohórquez, Alí: "La aristocracia venezolana frente a la Real Audiencia de Caracas: una razón para la Independencia de Venezuela", Congreso Bicentenario de Simón Bolívar, Caracas, ANH, 1983.

Venezuela (Provincia de) / Caracas / siglo XVIII / Aristocracia (mantuanos) / Audiencia / Administración colonial.

- Los ministros de la Audiencia de Caracas (1786-1810), Caracas, ANH, Coll. "Fuentes para la Historia Colonial de Venezuela", n. ${ }^{\circ}$ 174, 1984, 242 págs.

Venezuela (Provincia de) / Caracas / siglo XVIII / Aristocracia (mantuanos) / Audiencia / Administración colonial.

Lucena Salmoral, Manuel: El comercio caraqueño a fines del período español: mercados, comerciantes e instrumentos de cambio, Caracas, Universidad Santa María, 1984, Lecciones magistrales de doctorado, Dirección de Estudios para Graduados en Humanidades y Ciencias Sociales, n. ${ }^{\circ}$, 70 págs.

Venezuela (Provincia de) / siglo XVIII / Comercio libre (decreto de) / Comerciantes / Cosecheros. 
Mc Kinley, P. Michael: Pre-Revolutionary Caracas: Politics, Economy and Society 1777-1811, Cambridge, Latin American Studies n. ${ }^{\circ}$ 56, 1985, XVI-245 págs. Venezuela (Provincia de) / siglo XVIII / Comerciantes / Aristocracia (mantuanos) / Cosecheros / Haciendas / Propiedad (gran) / / Emancipación / Independencia.

“(Los) Marqueses de Caracas”, El Nuevo Diario, Caracas, 9 de junio de 1913, n. ${ }^{\circ} 154$.

Venezuela (Provincia de) / siglos XVII-XVIII / Títulos nobiliarios / Aristocracia (mantuanos) / Propiedad (gran).

Meza, Robinson: "La élite caraqueña frente a la reorganización político-administrativa de Venezuela en el último cuarto del siglo XVIII", Tierra Firme, abriljunio de 1991, n. ${ }^{o}$ 34, págs. 121- 134.

Venezuela (Provincia de) / Caracas / siglo XVIII / Reformas borbónicas / Aristocracia (mantuanos) / Audiencia / Administración colonial.

Miller, Gary M.: "Bourbon Social Engineering: Women and Conditions of Marriage in Eighteenth Century Venezuela", The Americas, January 1990, tomo 46, n. ${ }^{\circ} 3$, págs. 261-290.

Ejército / Élites (secundarias) / Derecho indiano / Oficiales / Hidalguía / Criollos / Matrimonio / Familia / Caracas / Mérida / Maracaibo / Puerto Cabello.

Rodríguez Mirabal, Adelina C.: La formación del latifundio ganadero en los llanos de Apure 1750-1800, Caracas, ANH, 1987, col. "Fuentes para la Historia de Venezuela Colonial", n. ${ }^{\circ} 193,371$ págs.

Apure / siglo XVII-XVIII / Haciendas / Tierra / Propiedad (gran).

Ruiz Tirado, Mercedes: "Consideraciones metodológicas para el estudio de las élites de poder en la Venezuela colonial", Tierra Firme, abril-junio de 1991, n. ${ }^{\circ}$ 34, págs. 135-142.

Venezuela (Provincia de) / siglo XVI-XVIII / Encomienda / Haciendas / Aristocracia.

— "Una familia de la élite merideña en el comercio atlántico (Contratación del tabaco barinés. Siglo XVII)", Boletín de la Academia de Mérida, 1994, año 1 , núm. 1, págs. 103-114.

Venezuela / Mérida / siglo XVII / Tabaco / Comercio / Haciendas / Maracaibo / Caracas / Atántico (comercio) / Élites / Comerciantes.

Sangroniz y Castro, José Antonio de: Familias coloniales de Venezuela, Caracas, Ed. Bolívar, 1943, tomo I.

Aristocracia / Mantuanos / Siglos XVI-XVIII / Títulos nobiliarios.

Troconis de Veracoechea, Ermila: "La "limpieza de sangre" a través de la Real Audiencia de Caracas", Memoria del segundo Congreso Venezolano de Historia, 3 ts., Caracas, ANH, 1975, tomo III, págs. 353-385.

Siglos XVI-XVII / Aristocracia / Administración colonial / Audiencia (ministros de la). 
Vásquez de Ferrer, Belín: "Formación y actuación de la élite marabina (17781821)", Ponencia presentada en el 47. ' Congreso Internacional de Americanistas, Nueva Orleans (EEUU), 7-11 de julio de 1991.

Venezuela / Gran Colombia / Maracaibo / Clases sociales / Pardos / Mestizos / Hidalguía / Españoles / Criollos / Comerciantes / Mercados / Hacendados / Cabildo / Comercio / Cacao / Iglesia / Poder político / Cádiz (Cortes de) / Independencia.

- "La élite marabina: contradicciones y acuerdos presentes en años de definiciones políticas: 1810-1830", Tierra Firme, abril-junio de 1991, n. ${ }^{\circ}$ 34, págs. 162-169.

Venezuela / Gran Colombia / Maracaibo / Clases sociales / Pardos / Mestizos / Hidalguía / Españoles / Criollos / Comerciantes / Mercados / Hacendados / Cabildo / Comercio / Cacao / Iglesia / Poder político / Cádiz (Cortes de) / Independencia.

- "Una élite regional: los comerciantes de Maracaibo en tiempos de crisis y ruptura con el realismo hispánico (1780-1821)", ponencia presentada en el II Congreso Nacional de Historia Regional, Barquisimeto (Venezuela), 23-25 de septiembre de 1992.

Venezuela / Gran Colombia / Maracaibo / Clases sociales / Pardos / Mestizos / Hidalguía / Españoles / Criollos / Comerciantes / Mercados / Hacendados / Cabildo / Comercio / Iglesia / Poder político / Cádiz (Cortes de) / Independencia.

- "La realidad política de Maracaibo en una época de transición, 1799-1830", Anuario de Estudios Bolivarianos, 1992, año II, n. o 2, págs. 225-317.

Venezuela / Gran Colombia / Maracaibo / Clases sociales / Pardos / Mestizos / Hidalguía / Españoles / Criollos / Comerciantes / Mercados / Hacendados / Cabildo / Comercio / Iglesia / Poder político / Cádiz (Cortes de) / Cortes (diputados a las) / Independencia. 